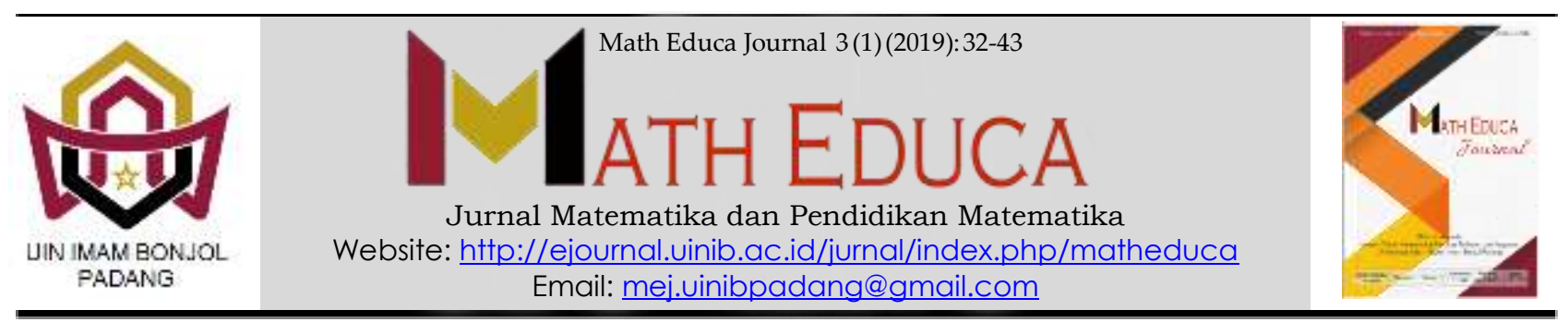

\title{
MODEL PEMBELAJARAN STUDENT TEAMS ACHIEVEMENT DIVISSION (STAD) PADA PEMBELAJARAN MATEMATIKA DI SMPN 46 SIJUNJUNG
}

\author{
1 Dwi Yuli, 2 Rivdya Eliza \\ 1,2Tadris Matematika, Fakultas Tarbiyah dan Keguruan, UIN Imam Bonjol Padang, Indonesia \\ Email: 1dwiyuli2215@gmail.com, 2riri_lagi@yahoo.com
}

Received: January 2019; Accepted: March 2019; Published: April 2019

\begin{abstract}
Abstrak
Penelitian ini mengkaji rendahnya minat belajar siswa dan hasil belajar matematika siswa kelas VIII SMP N 46 Sijunjung tahun pelajaran 2017/2018. Beberapa alasan pentingnya dilakukan penelitianini adalah untuk: 1) mengetahui minat belajar siswayang diajar dengan model pembelajaran kooperatif tipe STAD,2) mengetahui hasil belajar matematika siswa yang diajar dengan model kooperatif tipe STAD lebih tinggi dari hasil belajar matematika siswa yang diajar dengan model pembelajaran konvensional di kelas VIII SMP N 46 Sijunjung tahun pelajaran 2017/2018. Penelitian ini termasuk ke dalam jenis penelitian eksperimen semu (QuasiExperimental Research) dan menggunakan metode penelitian kuantitatif sehingga diperoleh informasi berkenaan dengan rendahnya minat belajar siswa dan hasil belajar matematika siswa. Subjek penelitian ini adalah seluruh siswa kelas VIII SMP N 46 Sijunjung. Pengambilan sampel menggunakan teknik purposive sampling. Hasil penelitian menunjukkan bahwa 1) minat belajar matematika siswa yang diajar dengan STAD dikategorikan baik dengan persentase $84,50 \%$ serta 2 ) hasil belajar matematika siswa yang diajar dengan model kooperatif tipe STAD lebih tinggi dari hasil belajar matematika siswa yang diajar dengan model pembelajaran konvensional. Terlihat dari perolehan rata-rata nilai tes kelas eksperimen 81,50 dan rata-rata nilai tes kelas kontrol 72,25. Persentase ketuntasan belajar siswa kelas eksperimen adalah 70\%, sedangkan pada kelas kontrol $40 \%$. Setelah dilakukan uji hipotesis menggunakan uji-t, diperoleh $t_{\text {hitung }}>t_{\text {tabel }}(2,68>1,68)$ dengan $\alpha=0,05$ pada selang kepercayaan 95\%, maka keputusannya adalah $H_{0}$ ditolak dan $H_{1}$ diterima.
\end{abstract}

Keyword: Student Team Achievement Division, Hasil Belajar, Minat Belajar

Abstract

This paper study about the interest and the low mathematics learning outcomes of eighth grade students of SMP N 46 Sijunjung in the school year 2017/2018. The aimsof this research are to know:1) the interest of student learning taught by the STAD cooperative learning model, 2) Mathematics learning outcomes from students that taught with the STAD type cooperative model in class VIII SMP N 46 Sijunjung 2017/2018 school year. This research is an experimental research and uses quantitative research methods. The subjects of this study were all eighth grade students of SMP N 46 Sijunjung. The sample taken by purposive sampling technique. The results showed that 1) the interest in mathematics learning of students taught with STAD was categorized as good with a percentage of $84.50 \%$ and 2) the mathematics learning outcomes of students taught with the STAD type cooperative model were higher than the mathematics learning outcomes of students taught with conventional learning models. It can be seen from the acquisition of the average value of the experimental class test 81.50 and

*Corresponding author.

Peer review under responsibility UIN Imam Bonjol Padang.

(c) 2019 UIN Imam Bonjol Padang. All rights reserved. 
the average value of the control class test 72.25. The percentage of student learning completeness in the experimental class was 70\%, while in the control class 40\%. After testing the hypothesis using the t-test, obtained $t$ count $>\mathrm{t}$ table $(2.68>1.68)$ with $\alpha \mathrm{i}=\mathrm{i} .05$ at the $95 \%$ confidence interval, then the decision is $\mathrm{Ho}$ rejected and $\mathrm{H} 1$ accepted.

Keyword: Student Team Achievement Division, Hasil Belajar, Minat Belajar

\section{PENDAHULUAN}

Pendidikan memegang peranan yang sangat penting dalam proses peningkatan kualitas sumber daya manusia (Dacholfany, 2017; Samsuni, 2017). Dalam proses pendidikan tersebut, berbagai faktor-faktor yang dapat meningkatkan prestasi akademik siswa harus diperhatikan dengan baik, misalnya minat belajar siswa (Buwono, t.t.; Laa, Winata, \& Meilani, 2017; Syah, Wardan, Rakhmat, \& Muchlis, 1997). Mengatakan bahwa minat(interest) secara sederhana dapat diartikan sebagai kecenderungan dan kegairahan yang tinggi atau keinginan yang besar terhadap sesuatu (Astuti, 2015; Fimansyah, 2015; Maesaroh, 2013; Nurhasanah \& Sobandi, 2016; Suharyat, 2009; Syah dkk., 1997). Menjelaskan bahwa minat memiliki pengaruh yang besar sekali terhadap kegiatan seseorang karena minat merupakan penyebab seseorang mengerjakan sesuatu yang diinginkannya. Minat yang besar tehadap sesuatu, menurut (Dalyono, 1997), merupakan modal yang besar artinya untuk mencapai/memperoleh benda atau tujuan yang diinginkan.
Dalam kaitannya dengan minat belajar, (Aritonang, 2008; Lestari, 2015; Muhson, 2009; Siagian, 2015) mengatakan bahwa minat belajar adalah ketertarikan dan kecenderungan yang tetap yang dimiliki oleh siswa untuk memperhatikan dan terlibat dalam aktivitas belajar karena menyadari pentingnya atau bernilainya hal yang dipelajari. Siswa yang memiliki minat terhadap subjek tertentu cenderung untuk memberikan perhatian yang lebih besar terhadap subjek tersebut (Indrawati, 2006; Rumini dkk., 2003; Slameto, 1988). Minat belajar yang besar, menurut (Dalyono, 1997; Simbolon, 2014), cenderung menghasilkan prestasi yang tinggi. Sebaliknya, minat belajar yang kurang akan menghasilkan prestasi yang rendah.

Dari paparan di atas dapat disimpulkan bahwa minat belajar siswa adalah hal yang penting untuk diperhatikan. Pada konteks sekolah, tanggung jawab untuk memperhatikan minat belajar siswa adalah tanggung jawab guru. (Slameto, 1988) mengatakaan bahwa untuk membangkitkan minat belajar siswa, guru memiliki peranan yang penting. Maka dari itu, guru harus memahami berbagai faktor yang dapat 
mempengaruhi minat belajar siswa. Menurut (Slameto, 1988), minat belajar dipengaruhi oleh faktor internal dan eksternal. Faktor internal terdiri dari a) faktor jasmaniah (seperti faktor kesehatan dan cacat tubuh), b) faktor psikologis (seperti intelegensi, perhatian, bakat, kematangan, dan kesiapan), dan c) faktor kelelahan. Adapun faktor eksternal, antara lain, adalah a) faktor keluarga, (seperti cara orang tua mendidik, relasi antara anggota keluarga, suasana rumah, keadaan ekonomi keluarga, pengertian orang tua, dan latar belakang kebudayaan), dan b) faktor sekolah, (seperti kompetensi guru, metode mengajar, kurikulum, relasi guru dengan siswa, relasi siswa dengan siswa, disiplin sekolah, alat pengajaran, waktu sekolah, standar penilaian diatas ukuran, keadaan gedung, metode belajar dan tugasrumah).

Seorang siswa yang minat belajarnya bagus akan belajar giat sehingga hasil belajarnya bagus, atau sebaliknya siswa yang tidak berminat sehingga menyebabkan malas belajar dan nilai belajarnya rendah. Hal ini sejalan dengan (Ali, 2004; Aviyah \& Farid, 2014; Gunarsa, 2008; Hurlock, 1993) bahwa minat merupakan sumber motivasi yang mendorong seseorang untuk melakukan apa yang ingin dilakukan ketika seseorang bebas memilih. Demikian juga (Ormrod, 2003) yang mengutip pendapat Hidi dan Derson, bahwa minat adalah bentuk dari motivasi intrinsik. Pengaruh positif minat akan membuat seseorang tertarik untuk melalukan sesuatu, sedang pengaruh negatifnya jika tidak ada minat maka tidak akan melakukan sesuatu.

Hasil belajar merupakan perolehan dari proses belajar siswa yang sesuai dengan tujuan pengajaran (Purwanto, 2000; Suratno, 2013). Menurut (Supriyono, 2009) bahwa hasil belajar adalah pola-pola perbuatan, nilai-nilai, pengertian, sikap, apresiasi dan keterampilan. Sedangkan (Sudjana, 2009) menyatakan bahwa hasil belajar adalah kemampuankemampuan yang dimiliki siswa setelah menerima pengalaman belajar.

Berdasarkan pendapat di atas, dapat dikatakan bahwa hasil belajar adalah hasil dari usaha atau tingkat keberhasilan siswa dalam mencapai tujuan yang dapat diberikan oleh guru mengenai kemajuan belajar siswa selama masa tertentu dan nilai-nilai yang terdapat dalam kurikulum. Dengan adanya hasil belajar tersebut maka siswa dapat melihat seberapa jauh kemampuan yang diperolehnya dalam proses belajar mengajar.

Keberhasilan proses kegiatan belajar mengajar pada pembelajaran matematika siswa dapat dilihat dari tingkat pemahaman, penguasaan materi, serta hasil belajar siswa. Semakin tinggi pemahaman dan penguasaan materi, maka semakin tinggi pula hasil belajar siswa. Namun dalam kenyataannya dapat dilihat bahwa hasil belajar matematika yang dicapai siswa masih rendah.Informasi yang diperoleh dari guru saat observasi adalah 
hasil belajar matematika siswa kelas VIII di SMP N 46 Sijunjung tahun ajaran 2016/2017 dengan jumlah siswa sebanyak 80 orang. Berikut data yang di peroleh.

Tabel 1. Persentase Ketercapaian KKM untuk Materi Pokok Relasi Fungsi di Kelas VIII SMP N 46 Sijunjung Semester Ganjil Tahun Ajaran 2016/2017

\begin{tabular}{lcc}
\hline $\begin{array}{l}\text { Materi } \\
\text { Pokok }\end{array}$ & $\begin{array}{c}\text { Jumlah Siswa } \\
\text { yang } \\
\text { Mencapai } \\
\text { KKM }\end{array}$ & $\begin{array}{c}\text { Persentase } \\
\text { Ketercapaian } \\
\text { KKM }\end{array}$ \\
\hline Relasi Fungsi & 18 & $22.50 \%$ \\
\hline
\end{tabular}

Sumber: Guru Bidang Studi Matematika SMP N 46 Sijunjung

Namun kenyataannya masih banyak hasil belajar siswa yang tidak mencapai ketuntasan belajar matematika. Berdasarkan wawancara dengan guru bidang studi matematika siswa kelas VIII SMP N 26 Sijunjung diperoleh hasil informasi bahwa hasil belajar matematika siswa banyak yang belum mecapai KKM yang telah diteatpkan. Adapun KKM untuk pelajaran matematika yang ditetapkan sekolah 75 .

Melihat rendahnya hasil belajar matematika siswa tersebut, peneliti berusaha mencari penyebab rendahnya hasil belajar tersebut dengancara melakukan wawancara dengan guru dan siswa, serta observasi (mengamati aktivitas guru dan siswa selama proses pembelajaran berlangsung). Berdasarkan hasil wawancara dengan guru diperoleh informasi bahwa kurangnya partisipasi antara guru dan siswa dalam proses pembelajaran. Misalnya pada saat guru mengajukan pertanyaan pada saat memberikan contoh soal, hanya beberapa siswa yang menjawab contoh soal yang diberikan guru. Walaupun guru telah memberikan kesempatan pada siswa untuk bertanya tentang soal yang diberikan, siswa hanya diam tanpa adanya respon terhadap pertanyaan guru. Sehingga ketika diberikan soal latihan, mereka kesulitan untuk mengerjakan latihan. Walaupun sudah diberikan bimbingan oleh guru, siswa masih kurang mampu untuk mengerjakan latihan. Dengan kondisi seperti ini, saat diberikan PR hanya beberapa siswa saja yang bisamengerjakannya. penelitian yang telah menunjukkan bahwa rendahnya hasil belajar siswa yaitu penelitian yang dilakukan oleh (Putri Islami, 2012) menyimpulkan bahwa rendahnya hasil belajar siswa disebabkan oleh kurangnya aktivitas siswa dan kurangnya pasrtisipasi anatara guru dan siswa dalam siswa dalam proses pembelajaran sehingga mengakibatkan siswa kurang mampu mengerjakan latihan.

Dari uraian di atas, terlihat bahwa proses pembelajaran yang dilakukan guru adalah siswa kurang berpartisipasi dalam mencari informasi yang luas tentang topik pembelajaran yang sedang dipelajari, sehingga pada saat pembelajaran berlangsung siswa hanya diam karena mereka merasa takut untuk memberikan jawaban mereka. Sedangkan Permendiknas RI nomor 41 tahun 2007 
mengamanatkan pelaksanaan pembelajaran yang dilakukan secara interaktif, inspiratif, menyenangkan, menantang, dan memotivasi peserta didik untuk berpartisipasi aktif. Kegiatan ini dilakukan melalui proses eksplorasi, elaborasi, dankonfirmasi.

Usaha yang dilakukan guru untuk meningkatkan aktivitas dan hasil belajar siswa adalah dengan membentuk kelompok belajar. Namun, ketika diadakan pembelajaran kelompok hanya sedikit siswa yang berpartisipasi dan aktif dalam diskusi kelompok tersebut. Hal ini dikarenakan siswa tidak memiliki pengetahuan tentang materi yang sedang dipelajari sehingga siswa tidak dapat ikut serta memberikan ide atau pendapat dalam diskusi tersebut. Sebagian siswa cenderung menunggu jawaban atau menyalin hasil kerja teman sekelompoknya. Selain itu ketika diberikan kesempatan untuk bertanya, hanya sedikit sekali siswa yang bertanya.

Guru perlu menyadari bahwa keterlibatan langsung siswa dalam pembelajaran dapat mempercepat penerimaan dan penyerapan terhadap materi pelajaran yang diberikan. Oleh karena itu, guru perlu merancang atau mempersiapkan kegiatan pembelajaran yang mampu melibatkan siswa dalam proses pembelajaran. Sejumlah hal di bawah ini dapat menjadi acuan bagi guru dalam upaya mengembangkan pelibatan langsung peserta didiknya ke dalam proses pembelajaran, yaitu: (1) Mengkaji bahan ajar/ materi pelajaran yang membutuhkan keterlibatan langsung peserta didik/ siswa. (2) Merancang bahan ajar yang memerlukan keterlibatan langsung peserta didik secara individual dan kelompok. (3) Merancang tugas/ pekerjaan untuk peserta didik mencari informasi/ pesan dari berbagai sumber (Agung \& Yansyah, 2010; Iskandar, 2010).

Model yang dapat digunakan untuk meningkatkan hasil belajar siswa, dimaksudkan sebagai wahana untuk menghubungkan guru dan siswa, serta siswa dengan materi pelajaran. Salah satu model yang digunakan dalam pembelajaran adalah model pembelajaran kooperatif yang memiliki beberapa variasi tipe di dalamnya, termasuk STAD. Menurut (Rusman, 2012) model STAD merupakan variasi pembelajaran kooperatif yang paling banyak digunakan dalam penelitian. Penerapan model Pembelajaran kooperatif tipe STAD kegiatan pelaksanaan pembelajarannya yaitu membagi siswa secara kelompok beranggotakan 4-5 orang yang beragam kemampuan, jenis kelamin, dan sukunya. Guru memberikan suatu pelajaran dan siswa-siswa di dalam kelompok memastikan bahwa semua anggota kelompok itu bisa menguasai pelajaran tersebut. Lebih jauh Slavin (Rusman, 2012) memaparkan bahwa: "Gagasan utama dibelakang STAD adalah memacu siswa agar saling mendorong 
dan membantu satu sama lain untuk menguasai keterampilan yang diajarkan guru".

Berdasarkan beberapa hasil penelitian menunjukkan bahwa penggunaan model pembelajaran kooperatif dapat meningkatkan hasil belajar siswa dibandingkan pembelajaran konvensional (ceramah, tanya jawab, dan pemberian tugas). (Amina, 2012) dalam skirpsinya, mengemukakan bahwa penggunaan model pembelajaran kooperatif tipe STAD dapat meningkatkan hasil belajar siswa pada materi membandingkan dan mengurutkan bilangan, dengan interprestasi peningkatan berkategori sedang. Penelitian yang telah menunjukkan bahwa penerapan model pembelajaran kooperatif tipe STAD dapat meningkatkan hasil belajar siswa yaitu penelitian yang dilakukan oleh (Esmawati, 2010; Sudana \& Wesnawa, 2017) menyimpulkan bahwa penerapan pembelajaran kooperatif tipe STAD dapat meningkatkan hasil belajar matematika siswa kelas VIII A SMP Negeri 5 Rengat pada materi relasi dan fungsi. Selanjutnya, penelitian yang dilakukan oleh (Eminingsih, 2010) menyimpulkan bahwa model pembelajaran kooperatif tipe STAD pada materi himpunan dapat meningkatkan hasil belajar siswa dan aktivitas siswa pada siswa kelas VII E SMP Negeri 3 Batang semester 2 tahun ajaran 2009/2010.

Berdasarkan permasalahan yang telah dipaparkan, peneliti bermaksud memberikan suatu solusi berupa penerapan model pembelajaran kooperatif tipe STAD. Dalam penerapan model pembelajaran ini siswa dituntut untuk lebih aktif dan mampu bertanggung jawab untuk mengerjakan tugas yang telah diberikan oleh guru. Model pembelajaran ini, diharapkan mampu meningkatkan minat belajar dan hasil belajar matematika siswa.

\section{METODE PENELITIAN}

\section{Jenis Penelitian}

Jenis penelitian ini adalah penelitian eksperimen semu, dengan model rancangan yang digunakan adalah randomized control group only design. Menurut Suharsimi (2006) rancangan penelitian randomized control group only design, dimana akan diambil dua kelas yang satu sebagai kelas eksperimen yang diberi perlakuan berupa model pembelajaran kooperatif tipe Student Teams Achievement Divission (STAD), dan kelas kontrol tanpa pemberian perlakuan apapun.

\section{Waktu dan Tempat Penelitian}

Penelitian dilaksanakan di SMPN 46 Sijunjung pada Tahun Ajaran 2017/2018 di kelas VIII. Waktu penelitian dilaksanakan pada tanggal 21 Juli 2017 s/d selesai. 


\section{Populasi dan Sampel}

Populasi pada penelitian ini adalah seluruh kelas VIII SMPN 46 Sijunjung berjumlah 80 siswa. Sampel adalah sebagian atau wakil dari populasi yang diteliti (Suharsimi, 2006). Sampel berarti contoh yaitu sebagian wakil populasi yang diteliti, (Suharsimi, 2006). Untuk penelitian ini sampel ditetapkan dua kelas dengan total siswa yang terlibat dalam penelitan adalah 40 orang.

\section{Prosedur Penelitian}

Prosedur penelitian dibagi atas tiga tahap, yaitu tahap persiapan, tahap pelaksanaan dan tahap akhir.Pada tahap persiapan, mempersiapkan semua yang diperlukan dalam penelitian seperti menetapkan jadwal penelitian,menentukan kelas sampel, dan mempersiapkan instrumen penelitian. Pada tahap pelaksanaan, pengumpulan data atau informasi sedang dilakukan pada kelas sampel.

Pada tahap akhir ini pada kelas eksperimen dan kelas kontrol diberikan tes untuk mengetahui hasil belajar kelas tersebut. Tes dan angket yang digunakan dalam penelitian ini sebelumnya sudah melalui tahap uji coba. Uji coba soal tes dilakukan untuk melihat daya beda, indeks kesukaran dan reliabilitas item yang akan diberikan pada siswa sehingga diperoleh soal tes dengan kualitas yang baik, setelah itu melaksanakan tes hasil belajar dan menyebarkan angket, ini digunakan untuk melihat hasil belajar matematika siswa serta melihat peningkatan minat belajar siswa.Tes hasil belajar yang dimaksud adalah tes akhir penelitian kelas eksperimen dan kelas kontrol, kemudian mengalinis tes akhir .

\section{Data, Intrumen, dan Teknik Pengumpulan Data}

Sumber data yang digunakan dalam penelitian ini adalahdata primer dan data sekunder.Data Primer dalam penelitian ini adalah hasil belajar matematika kelas eksperimen dan kelas kontrol dan minat belajar siswa matematika siswa kelas eksperimen. Data sekunder dalam penelitian ini adalah data tentang jumlah siswa dan hasil nilai ulangan harian 1siswa kelas VIII SMP N 46 Sijunjung.

Instrumen yang digunakan pada penelitian ini adalah tes akhir dan angket. Tes hasil belajar ini digunakan untuk melihat hasil belajar matematika siswa. Tes adalah sekumpulan soal-soal yang harus dikerjakan siswa dalam jangka waktu yang telah ditentukan. Tes yang diberikan berupa soal essay. Tes hasil belajar yang dimaksud adalah tes akhir penelitian kelas eksperimen dan kelas kontrol. Soal-soal pada tes akhir penelitian ini disusun berdasarkan indikator dari materi yang diajarkan selama penelitian berlangsung. Angket yang dibagikan kepada peserta didik berupa angket tertutup, yaitu peneliti sudah 
menyediakan jawabannya, sehingga responden tinggal memilih.Angket ini dimaksudkan untuk mengetahui data minat belajar siswa kelas VIII SMP N 46 Sijunjung pada mata pelajaran matematika dengan aspeknya meliputi perasanaan senang, keterlibatan, ketertarikan, dan perhatian siswayang kemudian dijabarkan dalam butirbutir pernyataan dalam instrumen angket.Angket minat belajar yang dimaksud adalah angket minat akhir penelitian kelas eksperimen.

Teknik pengumpulan data dilakukan dengan dengan menganalisis data tes akhir, yaitu dengan melakukan uji normalitas, uji homogenitas dan uji hipotesis. Uji normalitas ini bertujuan untuk melihat apakah kedua kelompok data berdistribusi normal atau tidak. Uji homogenitas variansi dilakukan untuk melihat apakah kedua kelompok data mempunyai variansi yang homogen atau tidak. Uji hipotesis bertujuan untuk mengetahui apakah hipotesis penelitian diterima atau ditolak. Maksudnya apakah hasil belajarmatematika siswa kelas eksperimen lebih baik dari pada kelas kontrol. Uji hipotesis dapat dilakukan setselah dilakukan uji normalitas dan uji homogenitas terhadap kelas sampel. Kemudian membagikan angket pada siswa, angket ini dimaksudkan untuk mengetahui data minat belajar siswa kelas VIII SMP N 46 Sijunjung pada mata pelajaran matematika dengan aspeknya meliputi perasanaan senang, keterlibatan, ketertarikan, dan perhatian siswa yang kemudian dijabarkan dalam butir-butir pernyataan dalam instrumen angket. Angket minat belajar yang dimaksud adalah angket minat akhir penelitian kelas eksperimen.

Selanjutnya dokumentasi. Tujuan dokumentasi yaitu untuk mengambil foto setiap kegiatan yang sedang berlangsung pada penelitian, yang berguna sebagai salah satu bukti telah melaksanakan penelitian.

\section{Teknik Analisis Data}

Hasil tes siswa diperoleh setelah penulis selesai memeriksa jawaban siswa. Data yang diperoleh dari tes akhir, dilakukan proses kegiatan analisa data dengan melakukan langkah-langkah sebagai berikut:

1) Uji normalitas ini bertujuan untuk melihat apakah kedua kelompok data berdistribusi normal atau tidak. Untuk uji normalitas ini menggunakan uji Liliefors

2) Uji homogenitas variansi dilakukan untuk melihat apakah kedua kelompok data mempunyai variansi yang homogen atau tidak. Pengujian ini dilakukan dengan menggunakan uji F. Pengujian homogenitas kelas sampel juga dapat dilakukan dengan uji $F$.

3) Uji hipotesis bertujuan untuk mengetahui apakah hipotesis penelitian diterima atau ditolak. Maksudnya apakah hasil belajar matematika siswa kelas eksperimen lebih 
baik daripada kelas kontrol. Uji hipotesis dapat dilakukan setelah dilakukan uji normalitas dan uji homogenitas terhadap kelas sampel. Rumus yang dikemukakan oleh Sudjana, (2009) dengan rumusan hipotesis adalah:

$\mathrm{H}_{\mathrm{o}}$ : Hasil belajar matematika siswa yang diajar dengan model koopreratif tipe STAD sama dengan Hasil belajar matematika siswa yang diajar dengan pembelajaran konvensional di kelas VIII SMP N 46 Sijunjung tahun ajaran 2017/2018.

$\mathrm{H}_{1}$ : Hasil belajar matematika siswa yang diajar dengan model koopreratif tipe STAD lebih tinggi dari pada Hasil belajar matematika siswa yang diajar dengan pembelajaran konvensional di kelas VIII SMP N 46 Sijunjung tahun ajaran 2017/2018.

Teknik analisis data pada angket yaitu untuk mengetahui derajat pencapaian minat digunakan dalam (Lubis, 2011; Martono, 2010):

$$
D P=\frac{\sum X}{N \times \sum \text { Item } \times \text { Skala Terting gi }}
$$

\section{Keterangan:}

DP = Derajat Pencapaian

$\sum X=$ Total Skor Hasil Pengukuran

$\sum$ item = Jumlah Butir Instrumen

$n \quad=$ Jumlah Responden

Selanjutnya derajat pencapaian nilai responden untuk minat menggunakan kriteria berikut:
Tabel 2. Derajat Pencapaian Minat Belajar Siswa

\begin{tabular}{cc}
\hline Derajat Pencapaian (\%) & Kriteria \\
\hline $90-100$ & Sangat Baik \\
$80-89$ & Baik \\
$65-79$ & Cukup \\
$55-64$ & Kurang \\
$0-54$ & Tidak Baik \\
\hline
\end{tabular}

\section{HASIL PENELITIAN DAN PEMBAHASAN}

Data hasil belajar matematika siswa pada kelas sampel diperoleh setelah diberikan tes akhir yang diikuti oleh 20 orang siswa pada kelas eksperimen dan 20 orang siswa pada kelas kontrol.

Setelah lembar jawaban siswa diperiksa dan dianalisis, diperoleh data bahwa hasil perhitungandistribusi frekuensi nilai berikut :

Tabel 3. Distribusi Frekuensi Nilai Kelas Eksperimen

\begin{tabular}{cccc}
\hline Interval & $\boldsymbol{x}_{\boldsymbol{i}}$ & $\boldsymbol{f}_{\boldsymbol{i}}$ & $\boldsymbol{f}_{\boldsymbol{k}}$ \\
\hline $65-70$ & 67,5 & 3 & 3 \\
$71-75$ & 73 & 4 & 7 \\
$76-80$ & 78 & 14 & 11 \\
$81-85$ & 83 & 0 & 11 \\
$86-90$ & 87,5 & 5 & 16 \\
$91-95$ & 93 & 2 & 18 \\
$96-100$ & 97,5 & 2 & 20 \\
\hline
\end{tabular}

Berdasarkan distribusi frekuensi di atas diperoleh nilai terendah pada hasil belajar kelas eksperimen adalah 65 dan nilai tertinggi 100. Dilihat berdasarkan ketuntasan secara individual siswa yang mendapat nilai memenuhi KKM sudah meningkat dari hasil belajar kelaseksperimen yaitu 14 siswa. KKM yang telah ditetapkan sekolah adalah 75, maka dapat dilihat pada kelas eksperimen yang 
tuntas adalah 14 orang dan yang tidak tuntas 6 orang.

Tabel 4. Distribusi Frekuensi Nilai Kelas Kontrol

\begin{tabular}{cccc}
\hline Interval & $x_{i}$ & $f_{i}$ & $f_{k}$ \\
\hline $55-60$ & 57,5 & 5 & 5 \\
$61-65$ & 63 & 2 & 7 \\
$65-70$ & 68 & 2 & 9 \\
$71-75$ & 73 & 3 & 12 \\
$76-80$ & 78 & 2 & 14 \\
$81-85$ & 83 & 3 & 17 \\
$86-90$ & 88 & 3 & 20 \\
\hline
\end{tabular}

Berdasarkan tabel distribusi frekuensi di atas diperoleh nilai terendah pada hasilkelas kontrol adalah 55 dan nilai tertinggi 90. Dilihat berdasarkan ketuntasan secara individual siswa yang mendapat nilai memenuhi KKM yaitu 75 hanya 8 siswa.Siswa kelas kontrol yang tuntas adalah 8 orang dan yang tidak tuntas adalah 12 orang.

Berdasarkan tabel skor nilai akhir hasil belajar dapat dilihat siswa yang mencapai KKM lebih tinggi dari kedua sampel adalah kelas eksperimen yaitu sebanyak 14 orang (70\%) dan berada dibawah KKM sebanyak 6 orang (30\%). Sedangkan kelas kontrol yang berada diatas KKM sebanyak 8orang (40\%), dan yang berada dibawah KKM adalah 12 orang (60\%).Berdasarkan skor diatas, dapat buat tabel hasil tes akhir sampel seperti berikut ini:

Tabel 5. Data Hasil Perhitungan Tes Hasil BelajarMatematikaSiswa Kelas Sampel

\begin{tabular}{cccccccc}
\hline Kelas & $\mathrm{N}$ & $\mathrm{T}$ & $\mathrm{TT}$ & $\bar{x}$ & $\mathrm{x}_{\max }$ & $\mathrm{x}_{\min }$ & $s$ \\
\hline Eksp. & 20 & 14 & 6 & 81,50 & 100 & 65 & 10,31 \\
Kontrol & 20 & 8 & 12 & 72,25 & 90 & 55 & 11,20 \\
\hline
\end{tabular}

Dari tabel di atas dapat dilihat bahwa rata-rata nilai matematika pada kelas eksperimen adalah 81,50 , lebih tinggi dari ratarata pada kelas kontrol yaitu 72,25. Nilai maksimum hasil tes yang diperoleh oleh kelas eksperimen adalah 100 lebih tinggi dari kelas kontrol yaitu 90, sedangkan nilai minimum yang diperoleh oleh kelas eksperimen adalah 65 dan kelas kontrol adalah 55. Sedangkan simpangan baku kelas eksperimen lebih rendah daripada simpangan baku kelas kontrol. Hal ini menunjukkan bahwa nilai pada kelas eksberimen lebih beragam.

Berdasarkan Kriteria Ketuntasan Minimal (KKM) yang ditetapkan di SMP N 46 Sijunjung yaitu 75, dari hasil tes hasil belajar matematika siswa pada kelas eksperimen diketahui bahwa nilai siswa yang mencapai KKM sebanyak 14 orang, sedangkan pada kelas kontrol sebanyak 8 orang, sehingga persentase ketuntasan belajar matematika siswa kelas eksperimen adalah 70\% dan pada kelas kontrol adalah 40\%. Sehingga dapat terlihat bahwa hasil belajar matematika siswa kelas eksperimen lebih baik dibandingkan hasil belajar matematika siswa kelas kontrol.

Data untuk nilai rata-rata hasil belajar siswa antara kelas eksperimen dengan kelas kontrol dapat disajikan dalam bentuk grafik sebagai berikut: 


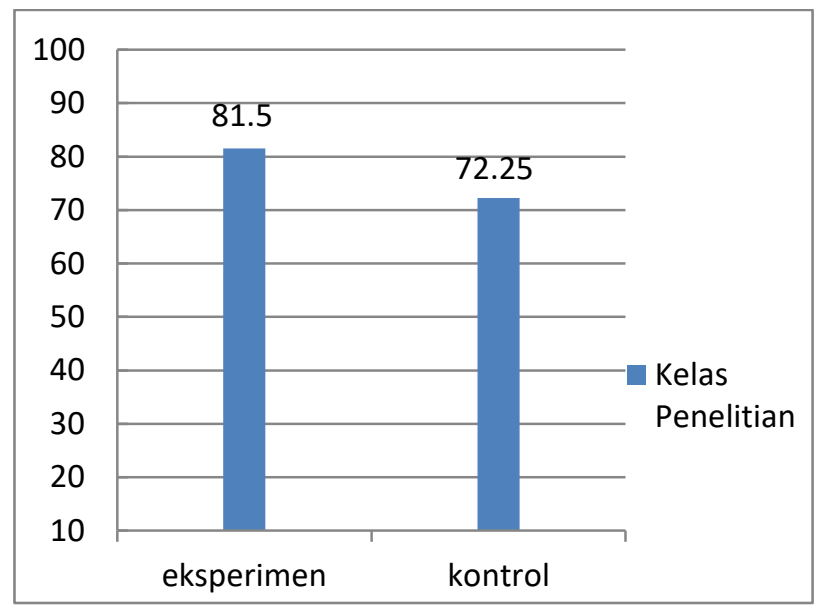

Gambar 1. Nilai Rata-Rata Kelas Eksperimen dan Kelas Kontrol

Berdasarkan analisis di atas dapat diketahui bahwa pada umumnya nilai rata-rata hasil belajar matematika siswa di kelas eksperimen lebih tinggi dibandingkan kelas kontrol. Maka dapat disimpulkan bahwa hasil belajar matematika siswa pada kelas eksperimen lebih baik dibandingkan kelas kontrol. Hal ini berarti hasil belajar matematika siswa yang diajarkan dengan pembelajaran kooperatif tipe Student Team Achievement Division (STAD) lebih baik dibandingkan siswa yang diajarkan dengan model pembelajaran konvensional.

Kesimpulan tentang data hasil tes hasil belajar siswa dilakukan analisis secara statistik. Sebelum uji statistik untuk hipotesis, terlebih dahulu dilakukan uji normalitas dan uji homogenitas.

1) Uji Normalitasmenggunakan uji Liliefors. Berdasarkan hasil uji Liliefors yang dilakukan, maka didapatkan sesuai pada tabel di bawah ini:
Tabel 6. Perbandingan $\mathrm{L}_{0}$ dan $\mathrm{L}_{\text {tabel }}$

\begin{tabular}{|c|c|c|c|c|c|}
\hline No & Kelas & $\mathrm{L}_{0}$ & $\mathrm{~L}_{\text {tabel }}$ & Kesimpulan & Keterangan \\
\hline 1 & Kontrol & 0,1129 & 0,190 & $\mathrm{~L}_{0}<\mathrm{L}_{\text {tabel }}$ & $\begin{array}{c}\text { Data } \\
\text { Normal }\end{array}$ \\
\hline 2 & Eksp. & 0,1078 & 0,190 & $\mathrm{~L}_{0}<\mathrm{L}_{\text {tabel }}$ & $\begin{array}{c}\text { Data } \\
\text { Normal }\end{array}$ \\
\hline
\end{tabular}

Selain itu untuk menentukan data berdistribusi normal atau tidak, penulis juga melakukan pengujian normalitas dengan sofware SPSS versi 16. Dengan menggunakan bantuan software SPSS versi 16 dapat dilihat hasil uji normalitas kedua kelas sampel bahwa sigfinikan kelas eksperimen dan kontrol lebih besar dari 0,05. Pada uji Kolmogorov Smirnov nilai probabilitas masing-masing kelas adalah 0,130 dan 0,200 pada uji Shapiro Wilk (0,216 dan 0,316 >0,05), sehingga dapat disimpulkan bahwa kedua kelas sampel berdistribusi normal.

2) Uji Homogenitas, berdasarkan Tabel distribusi $\mathrm{F}$ didapatkan nilai $F_{\left(\alpha ; v_{1}, v_{2}\right)}$ untuk taraf nyata $a=0,05$ dan derajat kebebasan $(d f)=\left(n_{1}-1, n_{2}-1\right)=(19,19)$ adalah 2,21. Maka diperoleh $F_{\text {hitung }}<$ $F_{\left(\alpha ; v_{1}, v_{2}\right)} \approx 1,78<2,21$ sehingga dapat disimpulkan bahwa kedua kelas sampel memiliki variansi yang homogen. Dengan menggunakan bantuan software Statistical Product and Service Solution (SPSS) Versi 16 dapat dilihat hasil uji homogenitas seperti pada tabel berikut: 
Tabel 7. Test of Homogeneity of Variances

Levene

\begin{tabular}{cccc} 
Statistic & $\mathrm{df} 1$ & $\mathrm{df} 2$ & Sig. \\
\hline, 010 & 1 & 38 &, 922 \\
\hline
\end{tabular}

Keputusan pada kolom Test of homogeneity of variances dapat dilihat nilai probabilitasnya 0,922 lebih besar dari 0,05, maka $H_{0}$ diterima, sehingga dapat disimpulkan sampel mempunyai variansi yang sama.

3) Uji Hipotesis, Uji hipotesis dilakukan untuk menentukan apakah hasil belajar siswa kelas eksperimen lebih meningkat dari pada kelas kontrol karena sampel merupakan data yang normal dan homogen, sehingga dilakukan pengolahan data dengan uji-t. Dengan $\alpha=0.05$ dan $d k=\left(n_{1}-1\right)+\left(n_{2}-1\right)=(20-1)+$ $(20-1)=38$, maka diperoleh $t_{\text {hitung }}=$ 2,68 sedangkan $t_{\text {tabeld }}$ dengan taraf kepercayaan 95\% adalah $t_{\text {tabel }}=1,68$. Karena $t_{\text {hitung }}>t_{\text {tabel }}$ maka hipotesis $H_{0}$ ditolak dan $\mathrm{H}_{1}$ diterima. Jadi hasil belajar matematika siswa yang diajarkan dengan pembelajaran kooperatif tipe Student Team Achievement Division (STAD) lebih tinggi dari hasil belajar matematika siswa yang diajarkan dengan strategi pembelajaran konvensional.

Berdasarkan hasil deskripsi dan analisis data diperoleh bahwa nilai ratarata kelas eksperimen lebih tinggi dari kelas kontrol. Perbedaan ini disebabkan karena perlakuan yang diberikan berbeda. Pada kelas eksperimen diberikan perlakuan khusus menggunakan model pembelajaran kooperatif tipe STAD (Students Team Achievement Division). Penggunaan model pembelajaran kooperatiftipe STADini siswa berminat untuk mencari apa yang belum dipahami dengan jalan bertanya dan diskusi, mengemukakan pendapat dalam penyelesaian masalah, dan mempertahankan pendapat karena siswa dipertemukan dalam satu kelompok yang heterogen.

Pembelajaran STAD ini menempatkan siswa ke dalam kelompokkelompok kecil secara heterogen yang sesuai kriteria dan tingkatan yang dipersyaratkan penelitian, kemudian siswa bekerja sama dalam kelompok untuk mendiskusikan serta mengerjakan soalsoal dan latihan yang ada di dalam Lembar Kerja Siswa (LKS) yang telah disediakan oleh guru. Pembagian kelompok yang heterogen menjadikan siswa saling berpacu satusama lain. Siswa yang memiliki kemampuan tinggi dapat belajar dan memberikan penjelasan kepada teman satu tim yang belum paham terhadap materi, maka dengan dibaginya kelompok secara heterogen ini akan terlihat kerja sama serta kekompakkan dari masing-masing kelompok karena 
setiap kelompok akan berpacu untuk mendapatkan nilai skor kelompok yang tinggi.Maka dari itu, untuk mendapatkan nilai yang tinggi setiap siswa harus paham terhadap materi pelajaran sehingga tidak terkendala dalam menjawab soal kuis yang dikerjakan secara individu. Untuk membantu siswa dalam memahami pelajaran maka guru memberikan kepada masing-masing kelompok sebuah LKS yang berisi ringkasan materi serta latihan mengenai soal-soal yang dipelajari.

Sebelum memulai materi terlebih dahulu penulis menginformasikan tentang konsep pembelajaran yang akan dilaksanakan. Di mana siswa pada awalnya siswa merasa keberatan dengan pembagian kelompok karena siswa dikelompokkan berdasarkan kemampuan siswa yang heterogen. Setelah siswa mengerti dan memahami dengan model pembelajaran yang akan diterapkan siswa diperbolehkan duduk dalam kelompoknya masing-masing. Sebelum guru memulai pelajaran, guru memberikan motivasi berupa kata-kata motivasi kepada siswa agar siswa memiliki kemauan dan minat dalam belajar matematika. Sehingga dengan adanya motivasi dan kemauan untuk belajar matematika, siswaakan menyukai pelajaran matematika. Sehingga hasil belajar matematika siswa meningkat dari yang sebelumnya.
Apabila ditinjau dari tes akhir, diperoleh bahwa hasil belajar tes akhir siswa kelas eksperimen dengan menerapkan model kooperatif tipe Student Team Achievement Division (STAD) lebih baik dari pada hasil belajar matematika siswa yang menerapkan model pembelajaran konvensional.Hal ini terlihat dari nilai rata-rata kelas eksperimen lebih tinggi daripada kelas kontrol. Rata-rata pada kelas eksperimen adalah 81,50 sedangkan kelas kontrol 72,25 dan nilai tertinggi kelas eksperimen adalah 100 sedangkan pada kelas kontrol 90, serta nilai terendah kelas eksperimen adalah 65 dan nilai terendah pada kelas kontrol adalah 55. Pada kelas eksperimen jumlah siswa yang mencapai nilai lebih dari atau sama dengan nilai KKM yang ditetapkan oleh SMP N 46 Sijunjung yaitu 75, sebanyak 14 siswa dengan persentase ketuntasan $70 \%$. Sedangkan pada kelas kontrol sebanyak 6 siswa dengan persentase ketuntasan 40\%. Sehingga dapat terlihat hasil belajar matematika siswa kelas eksperimen lebih baik dari hasil belajar matematika siswa kelas kontrol.

Hasil penelitian yang dilakukan di kelas VIII SMP N 46 Sijunjung, terlihat bahwa penerapan model kooperatif tipe Student Team Achievement Division (STAD) mampu meningkatkan hasil belajar 
matematika siswaselama proses pembelajaran berlangsung. Dari hasil penilaian pada aspek kognitif, terlihat hasil belajar matematika siswa pada kelas eksperimen ada peningkatan.

Hasil analisis data angket menunjukkan bahwa minat belajar matematika siswa kelas eksperimen yang diajar dengan model pembelajaran kooperatif tipe Student Team Achievement Division (STAD) menunjukkan persentase $84,50 \%$ yang dikategorikan kepada minat belajar matematika siswa baik, sehingga dengan minat yang baik ini akan memberikan hasil belajar yang baik pula.

\begin{tabular}{|c|c|c|c|}
\hline $\begin{array}{c}\text { Indikator Minat } \\
\text { belajar siswa }\end{array}$ & $\begin{array}{c}\text { No. } \\
\text { Pernyataan } \\
\text { Angket }\end{array}$ & Persentase & Kriteria \\
\hline Kesenangan & $1-9$ & $24,92 \%$ & - \\
\hline $\begin{array}{c}\text { Keterlibatan } \\
\text { siswa }\end{array}$ & $10-15$ & $17,21 \%$ & - \\
\hline $\begin{array}{l}\text { Ketertarikan } \\
\text { siswa }\end{array}$ & $16-21$ & $17,5 \%$ & - \\
\hline Perhatian siswa & $22-26$ & $24,88 \%$ & - \\
\hline Total & & $84,50 \%$ & Baik \\
\hline
\end{tabular}

Tabel di atas menjelaskan indikator minat belajar matematika siswa meliputi, kesenangan terdapat pada pernyataan no 1 sampai 9, keterlibatan siswa terdapat pada pernyataan 10 sampai 15, ketertarikan terdapat pada pernyatan no 16 sampai 21, perhatian siswa terdapat pada pernyatan no 22sampai 26 , kesadaran siswa terdapat pada pernyataan 27-30.

\section{SIMPULAN DAN SARAN}

\section{SIMPULAN}

Berdasarkan penelitian yang telah dilakukan, maka dapat diambil kesimpulan sebagai berikut: (1) Minat belajar siswa yang diajar menggunakan model pembelajaran kooperatif tipe Student Team Achievement Division (STAD)di kelas VIII SMP N 46 Sijunjung tahun ajaran 2017/2018 mendapatkan kriteria minat yang baik. Dapat dinyatakan dengan melihat persentase minat belajar siswa kelas eksperimen yaitu84,50\%. Derajat pencapaian perindikator minat belajar matematika siswa yaitu: kesenangan terdapat pada pernyataan no 1 sampai 9 dengan derajat pencapai $24,92 \%$ dengan derajat pencapai $17,21 \%$, keterlibatan siswa terdapat pada pernyataan 10 sampai 15 dengan derajat pencapaian 17,5\%, ketertarikan terdapat pada pernyatan no 16 sampai 21 dengan derajat pencapaian 13,92\%, perhatian siswa terdapat pada pernyatan no 22sampai 30 dengan derajat pencapaian 24,88\%. (2) Hasil belajar matematika siswa setelah diajar dengan model pembelajaran kooperatif tipe STADlebih tinggi dari pada Hasil belajar matematika siswa yang diajar dengan model pembelajaran konvensional di kelas VIII SMP N 46 Sijunjung tahun ajaran 2017/2018. Rata-rata tes akhir siswa pada kelas eksperimen adalah 81,50 dan pada kelas kontrol 72,25. Jika dilihat dari ketuntasan hasil tes akhir siswa, pada kelas eksperimen terdapat 12 siswa atau sebanyak70\% siswa yang memenuhi Kriteria 
Ketuntasan Minimun (KKM) dari 20 siswa yang ada. Sedangkan pada kelas kontrol terdapat 8 siswa atau sebesar 40\% siswa yang nilainya mencapai KKM dari 20 siswa yang ada.

Berdasarkan perolehan nilai di atas dapat terlihat bahwa Hasil belajar matematika siswa pada kelas eksperimen lebih tinggi dari Hasil belajar matematika siswa kelas kontrol. Hal ini juga dapat dilihat dari uji hipotesis diperoleh $t_{\text {tabel }}=1,68$ dan $t_{\text {hitung }}=2,68$ sehingga didapatkan $t_{\text {hitung }}>t_{\text {tabel }}(2,68>1,68)$ pada selang kepercayaan $95 \%$. Karena $t_{\text {hitung }}>t_{\text {tabel }}$ maka hipotesis dalam penelitian ini diterima, Hasil belajar matematika siswa yang diajarkan dengan metode STADlebih tinggi dari Hasil belajar matematika siswa yang diajarkan dengan pembelajaran konvensional.

\section{SARAN}

Berdasarkan kesimpulan penelitian ini, maka peneliti mengajukan saran-saran yaitu guru hendaknya dapat mempertimbangkan model pembelajaran kooperatif tipe STAD sebagai alternatif untuk meningkatkan hasil belajar siswa. Namun dalam penerapan model pembelajaran kooperatif tipe STAD membutuhkan waktu yang lama, jika tidak dikelola dengan baik. Sehingga bagi calon peneliti dan guru yang berminat dalam menerapkan model pembelajarn ini diperlukan persiapan pembelajaran yangbaik.

\section{DAFTAR PUSTAKA}

Agung, I., \& Yansyah, L. (2010). Meningkatkan kreativitas pembelajaran bagi guru: pedoman dan acuan guru dalam meningkatkan kreativitas pembelajaran pada peserta didik. Bestari Buana Murni.

Ali, M. (2004). Psikologi Remaja: Perkembangan peserta didik.

Amina, (2012) Penerapan Pembelajaran Kooperatif Tipe STAD dalam Meningkatkan Hasil Belajar Siswa Pada Materi Membandingkan dan Mengurutkan Bilangan. Skripsi, Ternate: UniversitasKhairun

Aritonang, K. T. (2008). Minat dan motivasi dalam meningkatkan hasil belajar siswa. Jurnal pendidikan penabur, 7(10), 11-21.

Astuti, S. P. (2015). Pengaruh kemampuan awal dan minat belajar terhadap prestasi belajar fisika. Formatif: Jurnal Ilmiah Pendidikan MIPA, 5(1).

Aviyah, E., \& Farid, M. (2014). Religiusitas, kontrol diri dan kenakalan remaja. Persona: Jurnal Psikologi Indonesia, 3(02).

Buwono, S. (t.t.). Pengaruh Minat Belajar Terhadap Hasil Belajar Pelajaran Ekonomi Siswa Kelas Xi Ips Man Pontianak. Jurnal Pendidikan dan Pembelajaran, 2(7).

Dacholfany, M. I. (2017). Inisiasi Strategi Manajemen Lembaga Pendidikan Islam Dalam Meningkatkan Mutu Sumber Daya Manusia Islami di Indonesia Dalam Menghadapi Era Globalisasi. At-Tajdid: Jurnal Pendidikan dan Pemikiran Islam, 1(01).

Dalyono, M. (1997). Psikologi Pendidikan. Penerbit Rineka Cipta. 
Ely, Fatmawati, (2015). Penerapan Model Pembelajaran Kooperatif Tipe STAD Dalam Meningkstksn Hasil Belajar Siswa Pada Materi Luas Permukaan Sisi Datar Bangun Ruang, Jurnal, Universitas Khairun

Eminingsih.(2010). Peningkatan hasil belajar matematika melalui pembelajaran kooperatif tipe STAD pada siswa,kelas VII,E,SMP Negeri 3 Batang. Jurnal UNNES

Esmawati.(2010). Penerapan Pembelajaran Kooperatif Tipe STAD untuk Meningkatkan HasihBelajar Matematika Siswa,Kelas VIII,A SMP Negeri,5 Rengat. Jurnal UIR

Fimansyah, D. (2015). Pengaruh Strategi Pembelajaran Dan Minat Belajar Terhadap Hasil Belajar Matematika. Judika (Jurnal Pendidikan UNSIKA), 3(1).

Gunarsa, S. D. (2008). Psikologi Perkembangan Anak Dan Remaja. BPK Gunung Mulia.

Hurlock, E. B. (1993). Adolescent Psychology. Tokyo: Kugakusha, Ltd.

Indrawati, Y. (2006). Faktor-Faktor Yang Mempengaruhi Kinerja Guru Matematika Dalam Pelaksanaan Kurikulum Berbasis Kompetensi (Kbk) Pada Sekolah Menengah Atas Kota Palembang. Jurnal Manajemen \& Bisnis Sriwijaya, 4(7), 41-58.

Iskandar, A. (2010). Meningkatkan Kreativitas Pembelajaran Bagi Guru. Jakarta: Bestari Buana Murni.

Laa, N., Winata, H., \& Meilani, R. I. (2017). Pengaruh Model Pembelajaran Kooperatif Tipe Student Teams Achievement Division Terhadap Minat Belajar Siswa. Jurnal Pendidikan Manajemen Perkantoran, 1(1), 141-150.
Lestari, I. (2015). Pengaruh waktu belajar dan minat belajar terhadap hasil belajar matematika. Formatif: Jurnal Ilmiah Pendidikan MIPA, 3(2).

Maesaroh, S. (2013). Peranan Metode Pembelajaran Terhadap Minat Dan Prestasi Belajar Pendidikan Agama Islam. Jurnal Kependidikan, 1(1), 150168.

Martono, N. (2010). Metode penelitian kuantitatif: Analisis Isi dan Analisis Data Sekunder (sampel halaman gratis). RajaGrafindo Persada.

Muhson, A. (2009). Peningkatan minat belajar dan pemahaman mahasiswa melalui penerapan problem-based learning. Jurnal Kependidikan: Penelitian Inovasi Pembelajaran, 39(2).

Nurhasanah, S., \& Sobandi, A. (2016). Minat belajar sebagai determinan hasil belajar siswa. Jurnal pendidikan manajemen perkantoran, 1(1), 135-142.

Ormrod, J. E. (2003). Educational Psychology: Developing Learners, 6th. Upper Saddle River, NJ: Merrill Prentice Hall.

Purwanto, M. N. (2000). Prinsip-prinsip dan teknik evaluasi pengajaran. Remaja Rosdakarya.

Putri Islami, RestuPenerapan Metode Pembelajaran Kooperatif ModelSTADUntuk Meningkatkan Hasil Belajar Matematika Siswa Kelas VIII.6 SMP N 1 Ujung Batu Roka Hulu,Jurnal FKIP Universitas Riau (4), 2-3

Rumini, S., Purwanto, E., Purwandari, M. S., Suharmini, T., Si, M., \& Ayriza, Y. (2003). Belajar dan Faktor-faktor yang Mempengaruhinya.

Rusman, M. P. (2012). Model-Model Pembelajaran Mengembangkan Profesionalisme Guru (edisi kedua). Jakarta: PT Raja Grafindo Persada. 
Samsuni, S. (2017). Manajemen sumber daya manusia. Al-Falah: Jurnal Ilmiah Keislaman dan Kemasyarakatan, 17(1), 113-124.

Siagian, R. E. F. (2015). Pengaruh minat dan kebiasaan belajar siswa terrhadap prestasi belajar matematika. Formatif: Jurnal Ilmiah Pendidikan MIPA, 2(2).

Simbolon, N. (2014). Faktor-Faktor Yang Mempengaruhi Minat Belajar Peserta Didik. Elementary School Journal Pgsd Fip Unimed, 1(2).

Slameto. (1988). Belajar dan Faktor-faktor yang Mempengaruhinya. Bina Aksara.

Sudana, I. P. A., \& Wesnawa, I. G. A. (2017). Penerapan Model Pembelajaran Kooperatif Tipe STAD Untuk Meningkatkan Hasil Belajar IPA. Jurnal Ilmiah Sekolah Dasar, 1(1), 1-8.
Sudjana, N. (2009). Penilaian Hasil Belajar Proses Belajar Mengajar. Bandung: PT Remaja Rosdakarya.

Suharsimi, A. (2006). Prosedur penelitian suatu pendekatan praktik. Jakarta: Rineka Cipta.

Suharyat, Y. (2009). Hubungan antara sikap, minat dan perilaku manusia. Jurnal Region, 1(3), 1-19.

Supriyono, A. (2009). Cooperatif learning. Yogyakarta: Putaka Belajar.

Suratno, S. (2013). Pengaruh Penerapan Metode STAD terhadap Hasil Belajar Ekonomi Ditinjau dari Minat Siswa di SMA N 10 Batanghari. Dinamika Pendidikan, 8(2).

Syah, M., Wardan, A. S., Rakhmat, M. F., \& Muchlis. (1997). Psikologi pendidikan: dengan pendekatan baru. Penerbit PT Remaja Rosdakarya. 